\title{
The Contribution of EU Funds to Wellbeing and Sustainable Development in Central European Countries
}

\author{
Mirjana Kranjac ${ }^{1}$, Uroš Sikimić ${ }^{2}$, Srđan Tomić ${ }^{3}$, Jelena Vapa-Tankosić ${ }^{4}$
}

\begin{abstract}
The European strategic goals are good standard of living, social and economic wellbeing and sustainability of the Planet Earth. Some of these requirements are contradictory. Often times, a successful economy exhausts nature well beyond its limits. Europe is achieving its goals by giving funds to many programs, thus enabling the elaboration of projects. The programs' and projects' goals and results must justify the global vision of European Union (EU) future, precisely defined in the document Europa 2020: to achieve a sustainable future. This paper is dealing with effects of the use of EU funds in Central European (CEE) countries. The authors are analyzing correlation between Happy planet index (HPI) and wellbeing indicator with absorption of EU funds. HPI shows the efficiency of residents of different countries in using environmental resources to lead long, happy lives. It reflects how satisfied are residents and what is the level of ecological constrain to reach this satisfaction. Happy planet index measures if it is possible to have good lives without depletion the Earth too much. It is combination of four factors: life expectancy, experienced wellbeing, inequality of outcomes and ecological footprint. The results of authors' research prove the hypothesis that funds are bringing wellbeing in terms of satisfaction of CEE citizen, but by rejecting the hypothesis that funds are leading to the sustainable development they come to the conclusion that this satisfaction is consequence of the use of natural resources over the limit needed for the sustainable future of the coming generations.
\end{abstract}

Key Words: sustainable development, foreign aid, economic integration, environment

JEL Classification: F35, F36, F64, C46.

\section{Introduction}

The European Union is aiming to enable satisfying life of its citizens, which means a high standard of living, social and economic wellbeing and sustainability of Europe and the whole Planet. Some of these requirements are contradictory. Often times, a successful economy exhausts nature well beyond its limits. Europe is achieving its goals by giving funds to many programs, thus enabling the elaboration of projects. These projects should lead EU to reach its strategic goals and to shape European future. However, this is not an easy job in a permanently and significantly changing world. The world is under at least three major pressures: social, economic and environmental. Their requests are usually confronted with each other. High life quality demands a good standard of living based on high earnings. On the other hand, high incomes are, in nowadays world, often the outcome of intensive use of natural resources and their

${ }^{1}$ University Novi Sad, Faculty of technical sciences Novi Sad, Serbia, * Corresponding author

2Singapore management university, Institute of Innovation and Entrepreneurship, Singapore.

${ }^{3}$ University Nikola Tesla, Faculty for engineering management, Belgrade, Serbia.

${ }^{4}$ University Business Academy, Novi Sad, Serbia. 
exhaustion. Human resources are depleted as well. Wealthy people, are they happy? This is a crucial question of modern civilization. The certain is that the working force that ensures their wealth is not satisfied.

The funds are filled by taxpayers' money and EU programs which are funding projects are shaped to justify their expectations defined in EU strategic papers. The program and project goals must lead to the global European vision, precisely defined in the document Europa 2020. This strategy shows how Europe should have the capability to deliver sustainable, smart and inclusive growth (Europe 2020). These three priorities are mutually connected and should help the EU and the Member States to reduce unemployment, boost productivity and intensify social cohesion. To achieve a sustainable future, Europe needs more satisfied residents, with jobs and in a more relaxing surrounding which ensures better lives. Better lives do not mean richer people, but people who have more freedom, surrounded by their families and rich and healthy nature.

The EU Commission is putting forward seven main initiatives to accelerate progress in each sector in focus. It proposes:

- $\quad$ "Innovation Union" for research and innovation, to turn ideas into products and services with new growth and working facilities.

- $\quad$ "Youth on the move" to facilitate the inclusion of young people into the labor market.

- $\quad$ "A digital agenda for Europe" to speed up development of high-speed internet with benefits of a digital global market.

- $\quad$ "Resource efficient Europe" to help shifting towards a low carbon economy, use of renewable energy sources based on energy efficiency and implement an integrated, efficient transport sector.

- $\quad$ "An industrial policy for the globalization era" to improve and make an environment for business to compete globally.

- $\quad$ "An agenda for new skills and jobs" to set up labor force career development with better matched labor supply and demand.

- $\quad$ "European platform against poverty" which should ensure social and territorial cohesion. Benefits of growth should be felt everywhere and reduce poverty among EU residents (Europe 2020).

The object of the authors' research in this article is absorption of EU funds during the EU budget period 2007-2013 and its reflection on Central European (CEE) countries' sustainable development.

The general goal is to identify and measure effects of the use of EU funds in Central European countries in terms of their sustainable development and quality of human living.

The specific goal is to discuss specific indexes that could be used to measure the results of projects financed from EU funds.

The authors propose the following hypothesis:

Hypothesis 1 (H1): EU funded projects are bringing better quality of life to CEE citizens.

Hypothesis 2 (H2): Results of EU funded projects are leading CEE countries to sustainable development. 
The structure of the paper is as follows: in the beginning the theoretical background is presented with definitions of the basic terms, followed by the literature review of scientific articles related to the topic of this paper. The section after explains the methodology used to measure the funding effects. Later on, the paper presents gained results and their analysis. The end of the paper holds the discussion about the posed hypothesis, leading to conclusions on further research.

\section{Theoretical background}

The European Union budget is constituted to cover its policies carried out at the European level in order to support: agriculture, trans-European networks, poorer regions, research and development etc. and its administrative costs. The European Commission's data show that $94 \%$ of expenditures belong to policies: programs and projects, $6 \%$ are devoted to administrative costs and less than $3 \%$ is spent on EU civil servants' salaries (EU budget at a glance, 2015).

In the previous budgetary period for the period 2007-2013, the EU had a budget of $€ 864.3 \mathrm{bn}$, what was $1.05 \%$ of the EU-27's gross national income (GNI) for this period (Q\&A on Interinstitutional Agreement on Budgetary Discipline and Sound Financial Management 2007-2013, 2006).

The EU had a budget of $€ 143$ billion for the year 2014. This is representing around $1 \%$ of the EU-28's gross national income. Over $90 \%$ are invested directly in Member States to fund thousands of projects, businesses, entrepreneurs, small and medium enterprises, supporting regions and cities, researchers and students (Georgieva, 2014; The EU budget for 2007-2013, 2014).

The Structural Funds are made up of the European Regional Development Fund (ERDF) and the European Social Fund (ESF). Together with the Common Agricultural Policy (CAP), the Structural Funds and the Cohesion Fund make up the great bulk of EU funding, and the majority of total EU spending.

The analysis presented in this paper covers European regional development fund (ERDF), Cohesion fund (CF) and European social fund (ESF) (Regional policy, 2015).

The ERDF promotes economic and social cohesion and focuses on several key priority areas (2007 to 2013 ERDF programs and resources, 2016):

- $\quad$ Sustainable jobs: Innovation and research;

- Infrastructure;

- $\quad$ Support for small and medium-sized enterprises (SMEs);

- The low-carbon economy.

The ERDF resources allocated depend on the category of region as presented (European Structural and Investment Funds, 2014):

- In more developed regions, at least $80 \%$ of funds must focus on at least two of these priorities;

- In transition regions, this focus is for $60 \%$ of the funds;

- This is $50 \%$ in less developed regions.

Some ERDF resources must be allocated towards low-carbon economy projects, only, as shown:

- More developed regions: 20\%;

- Transition regions: $15 \%$; 
- $\quad$ Less developed regions: $12 \%$.

The Cohesion fund supports actions in the field of environment and transport and promotes economic and social cohesion. In focus of CF are:

- Major infrastructure and environmental projects;

- Implementation of renewable energy sources and sustainable transport (Cohesion fund, 2015).

The European social fund (ESF) should reduce differences in living standards across EU and does the following (European social fund, 2014):

- Improving human resources and their adoption to the changing surrounding,

- Developing institutional capacities for the better inclusion of all groups.

There are many indicators which has been measures of absorption of EU funds. Some basic are the following:

- $\quad$ Contracted grants: These are sums for which contracts have been signed by European commission bodies: Managing authority and Implementing body, during a certain period of time.

- $\quad$ Paid grants: These are amounts which have been paid to the beneficiaries and which include advance payment for a certain period.

- $\quad$ Contracting ratio: It is a ratio between contracted grants for a certain period and available budget for the same period.

- $\quad$ Payment ratio: It is a ratio between paid grants for a certain period and available budget for the same period.

These indicators are presenting the spending of financial resources which is a quantitative measure and do not present a qualitative measure of the use of EU grants. The qualitative measures are even more important. For the EU taxpayers it is of significant value to have data about reaching the EU policies' goals. The main purpose of grants is to lead European Union to its strategic goals, preset in advance. EU has to develop mechanisms for the measurement of qualitative results. Only measurable indicators could show need for corrections of development routes and trace the road to a good future.

For the authors of the paper the main EU goal is sustainable development of EU and Planet Earth. The question is how to measure if the EU grants' results are empowering EU sustainability.

The authors implemented Happy Planet Index (HPI) as an indicator of the efficiency of different countries' residents to use environmental resources in order to lead long, happy lives. It reflects how satisfied the residents are and what the level of ecological constrain is to reach this satisfaction. Happy Planet Index measures if it is possible to have good lives without depletion the Earth too much. It is a combination of four factors: life expectancy, experienced wellbeing, inequality of outcomes and ecological footprint.

The Happy Planet Index is a measure of sustainable wellbeing of people. Wellbeing is presenting achievement of long, happy and sustainable life for nations and what they are doing to reach them.

Western countries with more wealthy residents are not on the top of the HPI ranking list. They recognize financial standard of living as a measure of their success. But some poor countries from Latin America and the Asia Pacific region have nations with high life expectancy and wellbeing. They protect the natural resources more and because of that have much smaller Ecological Footprints (Galli et al., 2014). 
The Happy Planet Index measures in which way the citizens could live good lives without costing the Earth too much. Good lives are long and happy lives, but lives in which environmental resources are efficiently used (Adelle et al., 2008).

\section{Literature review}

When talking about sustainable development authors of scientific articles discuss different topics. For some that means primarly higher incomes, for others, a cleaner environment. Some accept personal security as the main pillar of sustainable development and others, personal freedom. Some of these values are incompatible. Intensive economic growth may be damaging for the natural environment. Also, strengthening of personal security may cause limitation of personal freedoms (Soubbotina, 2004).

Sustainable development for other authors maximizes the long lasting benefits to humankind and takes care about environmental protection and should cover costs to repair degradation of natural resources (Asefa \& Kalamazoo, 2005). Some point out that sustainable development is important for all societies but is especially critical for poor ones, which depend more heavily on natural resources such as soils, rivers, fisheries and forests than richer nations do. Environmental problems in developing countries are primarily driven by poverty, while those of wealthier countries are driven by affluence and over consumption (Perkins et al., 2002).

Zidanšek explains that environmental sustainability indicators measure whether development improves quality of life and quality of environment. Usually, indicators of sustainable development are directed towards economic and environmental measures of development. The link between sustainable development indicators and satisfaction with life is often difficult to see for an individual. He poses the question whether sustainable development which should ensure good life of future generations requires that current generation sacrifices their happiness. The scholar argues that it is required to design strategies with goal to improve happiness and sustainability at the same time (Zidanšek, 2007).

The famous scientist whose focus of research is sustainable development says: "The sustainable development goals (SDGs) should therefore pose goals and challenges for all countries-not what the rich should do for the poor, but what all countries together should do for the global wellbeing of this generation and those to come. The SDGs will therefore need the unprecedented mobilization of global knowledge operating across many sectors and regions. Governments, international institutions, private business, academia, and civil society will need to work together to identify the critical pathways to success, in ways that combine technical expertise and democratic representation". He stresses the environmental sustainability and proposes that from 2015 to 2030, all nations should adopt strategies built on sustainable best practice technologies, appropriate market incentives, and individual responsibility. The world will move together towards low-carbon energy systems, sustainable food systems, sustainable urban areas and stabilization of the world's population supported by health services and education (Sachs, 2014). 
However, aggregate wealth impacts well-being indirectly, via positive channels, such as institutional quality and improvement in health, life expectancy and education. Wealth also brings about negative environmental degradations and other damages (Senik, 2014). Many research studies discuss the results of EU funded projects comparing to the level of allocated, contacted and absorbed financial resources. The papers are intended for member states of the EU, mostly. Many authors are occupied by analyzing benefits from Structural funds. A few authors present their conclusions, such as there not being good indicators of absorption rates in EU countries, like Georgescu (2007).

Problems of paid funds to the new members of the EU have also been noticed. Active approach by European policy bodies and authorities to this problem should be reached in the future. The funds should assist in achievement of national strategic plans in adjusting management procedures by adequate measures, Case et al. (2011).

Most papers so far appear to have presented the absorption of funds in a single country. Kalman (2010) has concluded that bed monitoring and control mechanism have not brought satisfied outcomes to Hungary. A few authors seek some econometric models to find possibilities for better absorption rates. Oana Gherghinescu (2010) includes an ARCH like model to measure results of structural funds in Romania. Corina Berica identifies the effects of Structural Funds in Romania and intends to draw conclusions about absorption barriers, Berica (2010).

The practical experience of some EU member states, for example Slovakia, has proven that the starting phase of the state, to create efficient and adequate administrative capacities for absorption of EU funds, is very important for future acceptable results, Knežević (2010).

Even through the political agenda in new member states put absorption rate of the structural funds as their priorities, it took a long post-accession period to increase it and to become successful, said Zaman and Georgescu (2009).

Study about results of Estonian local governments regarding Structural funds as strengthening factors of socio-economic development explains that capacity to absorb the funds was limited due to the administrative and financial barriers at local governments, Tartar (2010).

Marinov et al. (2006) analyzed difference between new (EU8) and old (EU15) member states and found different absorption capacities and managing problems.

Only a few scientific papers discuss how EU funds contribute to the sustainable development. The fast development is necessary but it must not be such to disable Earth's future.

Streimikiene et al. (2007) stresses that more wide use of renewable energy sources (RES) and efficient use of energy can make a valuable contribution to the meeting sustainable energy development. The authors' overview possibilities to use the EU Structural Funds available for new member states. They discuss conditions to finance sustainable energy projects and to overcome negative externalities of pollution and to implement positive incomes of knowledge and adoption of new technologies.

Some authors had discussions about the most relevant EU budgetary priorities relating to biodiversity (promoting the preservation and management of natural resources) and supporting regional cohesion within the Union. The financial allocations for 2007-2013 that uptakes of biodiversity funding possibilities in the Member States was very limited. 
Political will was missing at national level to support the EU's common environmental goals. There is a little evidence of systematic use of the funds to ensure funding of sustainability goals. Therefore, the EU budget for 2007-2013 cannot be considered as environmentally friendly (Kettunen \& Gantioler, 2014).

Perhaps the greatest failing of the EU system of environmental governance is the lack of adequate implementation. The current regulatory system focuses too much attention on procedures directives and not enough time dealing with effectiveness. Regulatory measures operate in a top-down fashion, focusing on the policy formulation and legislative process with little regard for outcomes. This stress on the legislation rather than on the capacity for enforcement potential for effective reaction to environmental problems (Cameron \& Joas, 2007).

\section{Methodology}

HPI scores are calculated by multiplying the average life expectancy of residents in a country by their average experienced wellbeing in this country. This product is multiplied by the inequalities between people within a country. These inequalities reflect differences in the duration of their lives and their happiness, based on the distribution in each country's life expectancy and wellbeing data. Inequality of outcomes is expressed as a percentage. This numerator is than divided by country's Ecological Footprint per capita which is an average impact that each human on the Earth places on the environment. It is expressed by using global hectares (gha) per person (Borucke et al., 2012).

In general, the HPI reflects the average years of happy life per unit of planetary resources consumed.

Equation (1) illustrates, approximately, how HPI scores are calculated.

HPI $\equiv \frac{(\text { Life expectancy } x \text { Experienced wellbeing }) \mathrm{x} \text { Inequality of outcomes }}{\text { Ecological Footprint }}$

Note: The equation is approximate because it leaves out the statistical adjustments.

There are four elements encompassed within HPI are (Marks et al., 2006):

- Life expectancy: the average life expectancy of residents in a country based on data collected by the United Nations. It is commonly used as an overall indicator of the standard of health in a country (Veenhoven, 1996).

- Experienced wellbeing: is an indicator of how satisfied the residents of each country say they feel with life overall, on a scale from zero to ten, based on data collected (Stoll et al., 2012). It is the average of all responses within the population to the question: "Please imagine a ladder with steps numbered from zero at the bottom to 10 at the top. Suppose we say that the top of the ladder represents the best possible life for you; and the bottom of the ladder represents the worst possible life for you. On which step of the ladder do you feel you personally stand at the present time, assuming that the 
higher the step the better you feel about your life, and the lower the step the worse you feel about it? Which step comes closest to the way you feel?”' (Naderi et al., 2015).

- Inequality of outcomes: is a measure of inequality of the distribution of life expectancy and experienced wellbeing scores in a particular country. These are inequalities between people within a country, in terms of how long they live, and how happy they feel, based on the distribution in each country's life expectancy and wellbeing data. Inequality of outcomes is expressed as a percentage (Atkinson, 1970).

- Ecological Footprint: is the average part of land needed, per capita of population, to sustain a typical consumption patterns in this country. It includes:

the land required to provide the renewable resources people use (most importantly food and wood products)

$>\quad$ the area occupied by infrastructure

$>\quad$ the area required to absorb $\mathrm{CO} 2$ emissions.

It shows need of land and water area for human population required to produce the necessary resource and to absorb its carbon dioxide emissions (Happy planet index, 2016; Monfreda et al., 2004). The ecological footprint is described as demand for ecosystem products and services which are result of different land use types: forest land, cropland, fishing ground, gazing land, built-up land (Ewing et al., 2010).

It is a measure of consumption and not production. The emission is associated with the place where the product is consumed and not where it is produced. If a PC is produced in Germany, and purchased in Poland, the CO2 associated with the manufacture will be counted within Poland's Ecological Footprint, not German's (Kitzes et al., 2007; Kitzes et al., 2008).

Ecological Footprint is expressed by standardized unit: global hectare per person. A global hectare (gha) is a measurement unit for quantifying both the ecological footprint of people or activities as well as the biocapacity of the earth or its regions. One global hectare represents the average productivity of all biologically productive areas (measured in hectares) on earth in a given year. Actually, it reflects the average impact that each resident of a country places on the environment, based on data prepared by the Global Footprint Network (Methodology and sources, 2016).

The Global Footprint Networks has calculated that in 2012, 1.73 gha is available for each person living on Earth. If a country's Ecological Footprint per capita is more than 1.73 gha, the residents of that country are demanding more than is environmentally sustainable (Happy Planet Index 2016, 2016).

The Happy Planet Index provides a compass to guide nations, and shows that it is possible to live good lives without costing the Earth.

The authors calculate Pearson correlation coefficient to find correlation of paid EU aid and Happy Planet Index (HPI) for Central European countries. HPI index is established as measure of citizen's satisfaction and their efficient, enviroment friendly use of the nature. It could be said that it measures sustainable development which contributes the European values. The HPI simplified the picture and analyses what we exploit as inputs (resources), and what will be results (quality and length of human lives).

The authors tested the influence of paid EU grants on a)wellbeing of CEE citizens and b)sustainable development of CEE countries. They did the following calculations: 
- For H1: If there is correlation between two values: paid EU grants per capita and better quality of life of CEE citizens presented by the data of their wellbeing.

- For H2: If there is dependence between two values: paid EU grants per capita and HPI index which represents sustainable growth.

To find correlation, authors of the paper applied Pearson correlation coefficient (PCC) which calculates statistical relationship between two random variables or two sets of data. It is very often used to measure correlation (Statistics how to, 2016). Calculation of PCC is as following: the covariance of the two variables is devided by the product of their standard deviations like in equation (2):

$$
\varrho \mathrm{X}, \mathrm{Y}=\operatorname{corr}(\mathrm{X}, \mathrm{Y})=\frac{\operatorname{cov}(\mathrm{X}, \mathrm{Y})}{\sigma \mathrm{X} \sigma \mathrm{Y}}=\frac{\mathrm{E}[(\mathrm{X}-\mu \mathrm{X})(\mathrm{Y}-\mu \mathrm{Y})]}{\sigma \mathrm{X} \sigma \mathrm{Y}}
$$

The insignie in equation are:

E: expected value operator

Cov: covariance

Corr: alternative notation for Pearson's correlation (Bao \&Weng, 2011).

The variables which are analyzed are:

For Hiphotesys 1:

- $\quad \mathrm{Xi}$ variables are: $\mathrm{n}$ data for paid EU grants for the budget period 2007-2013;

- Yi variables are: $\mathrm{n}$ data for wellbeing as a factor of HPI index;

For Hiphotesys 2:

- $\quad$ Xi variables are: $\mathrm{n}$ data for paid EU grants for the budget period 2007-2013;

- $\quad$ Yi variables are: $\mathrm{n}$ HPI indexes of CEE countries;

Number $\mathrm{n}$ is the number of countries taken into the calculation. The equation for sample correlation coefficient between xi and yi group of data is given in the equation (3) as:

$$
\begin{aligned}
& \operatorname{rxy}=\frac{\sum x i y i-n \overline{x y}}{(n-1) S x S y} \\
& =\frac{n \sum x i y i-\sum x i \sum y i}{\sqrt{n \sum x^{2}-\left(\sum x i\right)^{2}} \sqrt{n \sum \mathrm{yi}^{2}-\left(\sum y\right)^{2}}}
\end{aligned}
$$

where $\mathrm{x}_{\mathrm{i}}$ and $\mathrm{y}_{\mathrm{i}}$ are the samples of values and $\mathrm{s}_{\mathrm{x}}$ and $\mathrm{s}_{\mathrm{y}}$ are the sample standard deviations of $\mathrm{X}$ and $\mathrm{Y}$.

\section{Empirical data and analysis}

In Table 1 are presented basic data about CEE countries, GDP, population, GDP per capita, paid grants, payment ratio, contracted grants, contracted ratio. All data and calculations are for the budget period 2007-2013 (EU funds in Central and Eastern Europe, 2014). 
Table 1: Basic and EU funds absorption data for CEE countries

\begin{tabular}{|l|l|l|l|l|l|l|l|}
\hline Countries & $\begin{array}{l}\text { AnnualGDP } \\
\text { (EUR } \\
\text { billion) }\end{array}$ & $\begin{array}{l}\text { Population } \\
\text { (million) }\end{array}$ & $\begin{array}{l}\text { GDP } \\
\text { per } \\
\text { capita } \\
(1000 \\
\text { EUR) }\end{array}$ & $\begin{array}{l}\text { Paid } \\
\text { grants } \\
\text { billion })\end{array}$ & $\begin{array}{l}\text { Payment } \\
\text { ratio } \\
(\%)\end{array}$ & $\begin{array}{l}\text { Contracted } \\
\text { grants } \\
\text { (EUR } \\
\text { billion) }\end{array}$ & $\begin{array}{l}\text { Contracted } \\
\text { ratio (\%) }\end{array}$ \\
\hline Romania & 150.66 & 19.95 & 7.55 & 10 & 52 & 20.3 & 106 \\
\hline Poland & 403.08 & 38.48 & 10.48 & 52.5 & 78 & 68.2 & 102 \\
\hline Bulgaria & 42.00 & 7.2 & 5.83 & 5.1 & 77 & 7.7 & 115 \\
\hline Czech R. & 154.94 & 10.51 & 14.74 & 18.1 & 69 & 25.2 & 96 \\
\hline Slovakia & 75.21 & 5.42 & 13.88 & 7.6 & 65 & 13.1 & 112 \\
\hline Latvia & 24.06 & 1.99 & 12.09 & 3.9 & 86 & 4.8 & 105 \\
\hline Hungary & 103.3 & 9.88 & 10.46 & 21.7 & 87 & 28.0 & 112 \\
\hline Lithuania & 36.29 & 2.94 & 12.34 & 6 & 88 & 6.8 & 100 \\
\hline Estonia & 19.53 & 1.32 & 14.80 & 3 & 87 & 3.3 & 98 \\
\hline Slovenia & 37.25 & 2.06 & 18.08 & 3.4 & 83 & 4.3 & 104 \\
\hline Soure: Emat & & & & & & \\
\hline
\end{tabular}

Source: Eurostat data, 2014

Table 2 presents data for Happy Planet Index, Wellbeing, Footprint and Inequality data. In the bottom row are results of calculated Pearson correlation coefficients (PCC). Correlation coefficients are proving the dependence between: HPI, Wellbeing, Ecological footprint and Inequality and paid grants per capita in CEE countries.

Table 2: Correlation between paid grants per capita and HPI, Wellbeing, Footprint and Inequality

\begin{tabular}{|l|l|l|l|l|l|}
\hline Countries & $\begin{array}{l}\text { Paid grants } \\
\text { per capita (Xi) } \\
\text { in 1000 EUR }\end{array}$ & HPI (Yi) & Wellbeing(Yi) & Footprint(Yi) & Inequality(Yi) \\
\hline Romania & 0.501253 & 28.8 & 2.7 & 2.7 & 19 \\
\hline Poland & 1.364345 & 27.5 & 4.4 & 4.4 & 11 \\
\hline Bulgaria & 0.708333 & 28.4 & 3.3 & 3.3 & 19 \\
\hline Czech R. & 1.722169 & 27.3 & 5.2 & 5.2 & 9 \\
\hline Slovakia & 1.402214 & 28.2 & 4.1 & 4.1 & 13 \\
\hline Latvia & 1.959798 & 17.1 & 6.3 & 6.3 & 14 \\
\hline Hungary & 2.196355 & 26.4 & 2.9 & 2.9 & 15 \\
\hline Lithuania & 2.040816 & 21 & 5.8 & 5.8 & 11 \\
\hline Estonia & 2.272727 & 17.9 & 6.9 & 6.9 & 12 \\
\hline Slovenia & 1.650485 & 24.6 & 6.1 & 5.8 & 19 \\
\hline PCC & & $\mathbf{0 . 6 9 8}$ & $\mathbf{+ 0 . 6 4 5}$ & $\mathbf{0 . 6 5 4}$ & $\mathbf{- 0 . 6 3 8}$ \\
\hline
\end{tabular}

Source: Eurostat data, 2014 and authors 
The Pearson correlation coefficient between Paid grants per capita and HPI is -0.698. This result shows high negative correlation which is defined if PCC is in interval: -0.5 to 1.0. Negative correlation means that when the paid aid is getting bigger, indicators of sustainable development are worse (HPI decreases). When HPI is bigger, country has developed in the direction of ecology. HPI index is calculated in such way that bigger score means better ranking of a country.

Big negative correlation gives conclusion that better countries (in terms of HPI index: sustainable growth) are not those which used EU grants the most, just the opposite. This indicates that EU grants haven't improved ecological issues in CEE countries.

Figure 1 is graphically presentation of negative correlation among HPI and Paid grants per capita which is proved by calculating Pearson correlation coefficient (Table 2).

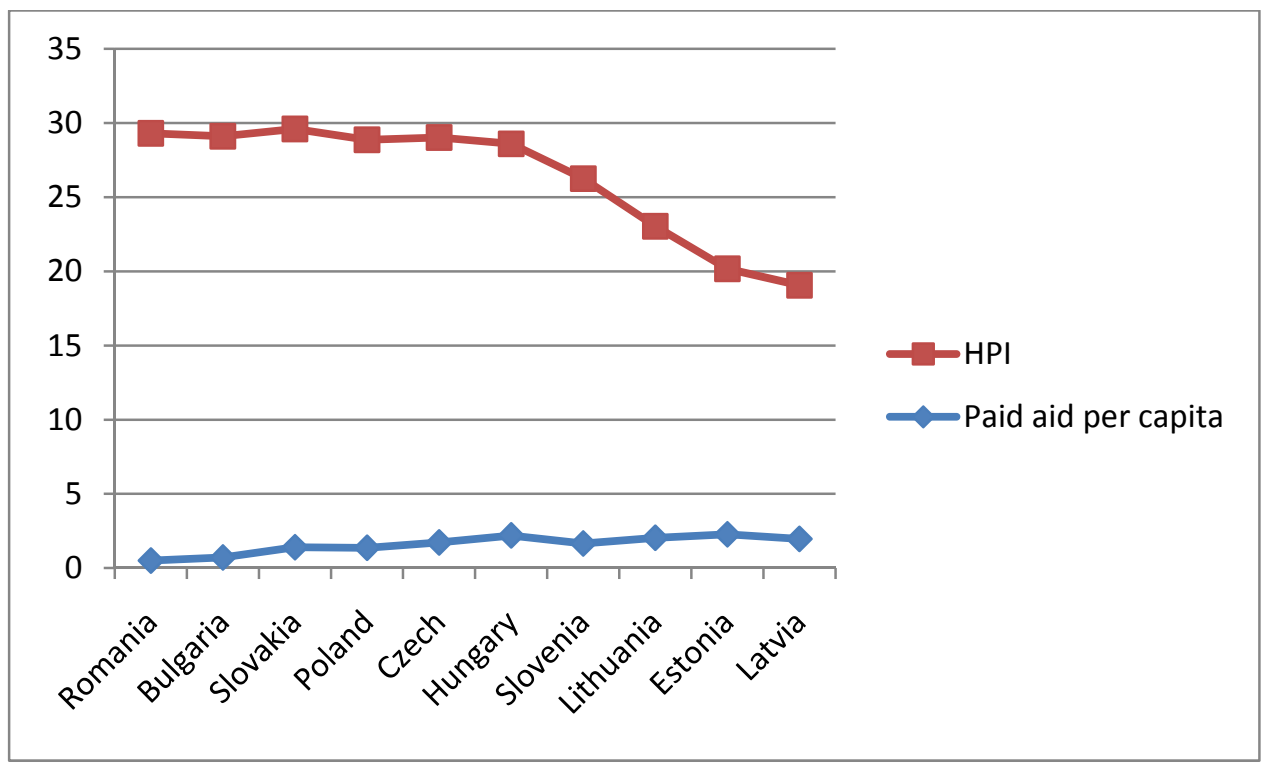

Figure 1: Negative correlation among HPI and Paid grants per capita Source: authors

The Pearson correlation coefficient between Paid aid per capita and Wellbeing is +0.645. This result shows high positive correlation which is defined if PCC is in interval: 0.5 to 1.0. Dependence is graphically presented in Figure 2. Positive correlation means that when the Paid grants are getting bigger, Wellbeing is increasing. 


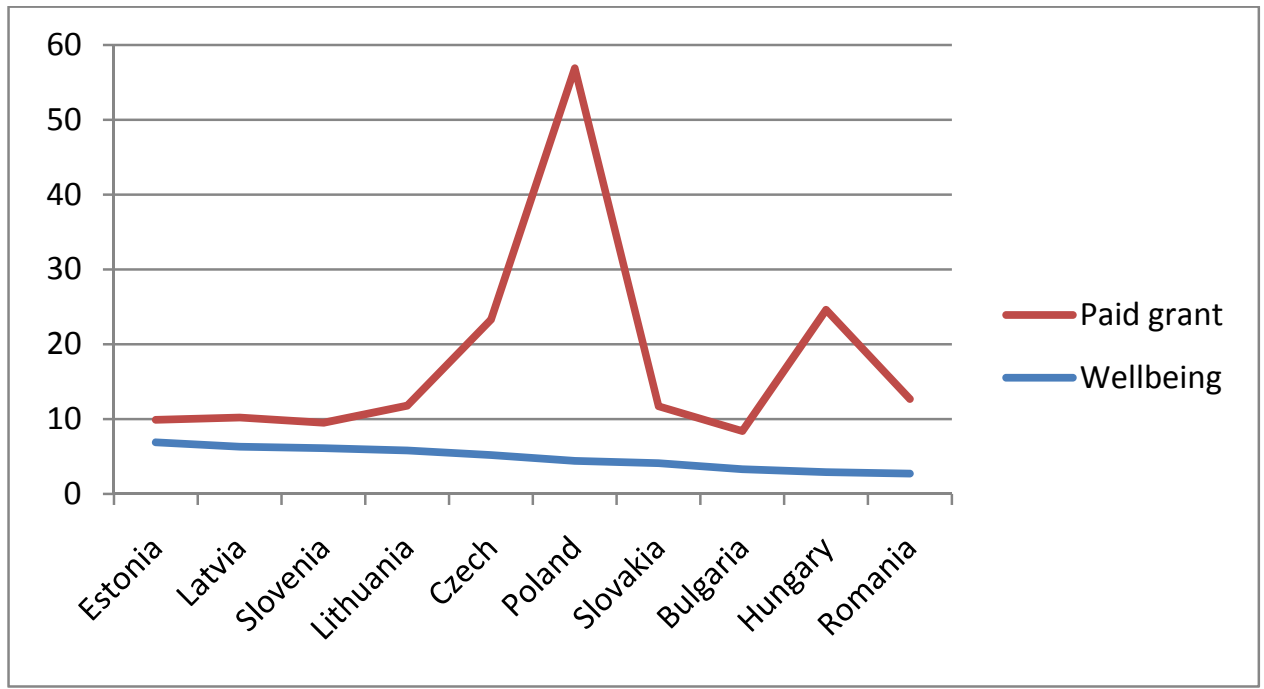

Figure 2: Positive correlation among Wellbeing and Paid grants per capita

Source: authors

The Pearson correlation coefficient between Paid grants per capita and Footprint is $+\mathbf{0 . 6 3 8}$ what shows high positive correlation which is defined if PCC is in interval: 0.5 to 1.0. Positive correlation means that when the Paid grants are getting bigger, Footprint is increasing. When it is increasing, nature is more exhausting. The positive correlation is graphically illustrated in Figure 3.

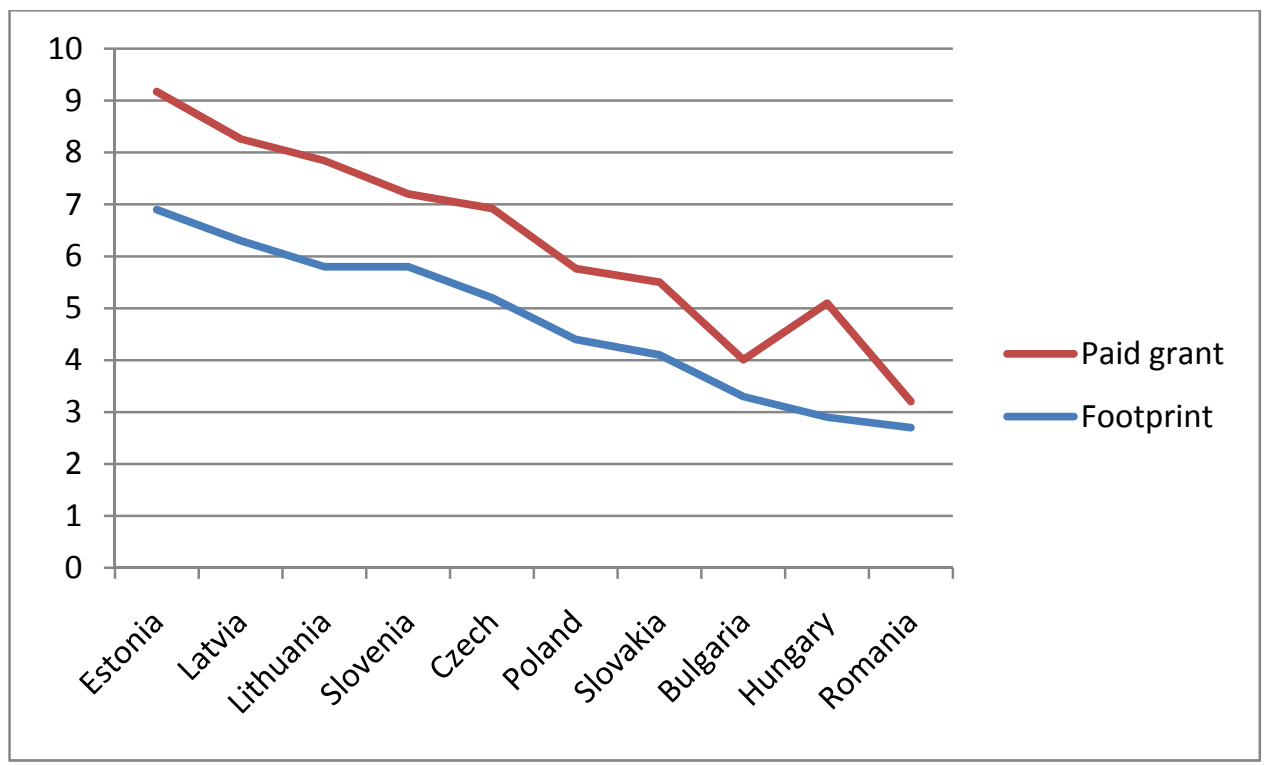

Figure 3: Positive correlation among Footprint and Paid aid per capita

Source: authors 
The Pearson correlation coefficient between Paid grants per capita and Inequality is $\mathbf{0 . 6 6 3}$ what shows high negative correlation which is defined if PCC is in interval: -0.5 to 1.0 (Figure 4). Negative correlation means that when the Paid grants are getting bigger, Inequality decreases, there are less differences between people.

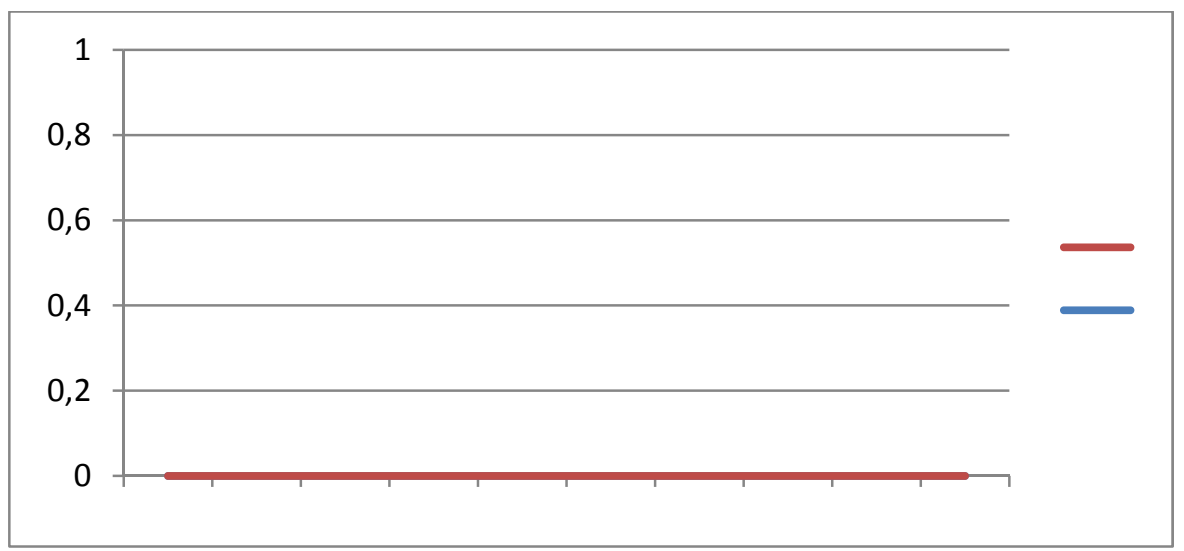

Figure 4: Negative correlation among Inequality and Paid aid per capita

\section{Source: authors}

Table 3 shows, as additional prove, that CO2 emission per capita is growing simultaniously with paid grants per capita in CEE countries. Pearson correlation coeficient is $+0,5294$ (significant positive correlation).

Table 3: Correlation between paid grants per capita and CO2 emission

\begin{tabular}{|l|l|l|l|l|}
\hline Countries & $\begin{array}{l}\text { Population } \\
2014 \text { (million) }\end{array}$ & $\begin{array}{l}\text { CO2 emission 2014 } \\
\text { (in million tones of } \\
\text { CO2 equivalents) }\end{array}$ & $\begin{array}{l}\text { CO2 per capita } \\
2014\end{array}$ & $\begin{array}{l}\text { Paid grant per } \\
\text { capita 2014 }\end{array}$ \\
\hline Romania & 19.95 & 110.4 & 5.53 & 501.25 \\
\hline Poland & 38.48 & 382 & 9.92 & 1.364 .34 \\
\hline Bulgaria & 7.2 & 55.4 & 7.69 & 708.33 \\
\hline Czech R. & 10.51 & 126.8 & 12.065 & 1.722 .17 \\
\hline Slovakia & 5.42 & 40.8 & 7.52 & 1.402 .22 \\
\hline Latvia & 1.99 & 11.6 & 5.83 & 1.959 .8 \\
\hline Hungary & 9.88 & 57.7 & 5.84 & 2.196 .36 \\
\hline Lithuania & 2.94 & 19.2 & 6.53 & 2.0408 .16 \\
\hline Estonia & 1.32 & 21.2 & 16.06 & 2.272 .72 \\
\hline Slovenia & 2.06 & 16.7 & 8.11 & 1.650 .48 \\
\hline PCC & & & $\mathbf{+ 0 . 5 2 9 4}$ & \\
\hline
\end{tabular}

Source: Total greenhouse gas emissions by countries (including international aviation and indirect CO2, excluding LULUCF), million tonnes of CO2, equivalents and Eurostat - Population and authors 


\section{Discussion}

The presented results clarify achievements of EU grants which are paid for realization of projects. These projects sholud bring to realization European Union policy targets. The authors took into the consideration paid grants. Available or contacted amounts are not the subject of research due to the fact that only paid sums are reflecting realized projects and bring requested results.

In the Thompson, S. et al. (2007) report about European unhappy index stated that snapshot done have shown how Europe was faring. But how did it get here? „Examining trends in well-being and footprint over the last four decades reveals a depressing picture. Modest improvements to well-being, mainly driven by increased life expectancy, can be observed over this period, although - relative to the rest of the World - quality of life in Europe was already good in the 1960s. But over the same time period per capita carbon footprints have risen by as much as 75 per cent. In other words, marginal gains in wellbeing have been bought at an unsustainably high environmental price - the efficiency of delivering well-being has actually fallen by around 10 per cent when it should have been rising .

The authors of this paper did reasearch about European attempt to improve its future through its granting policy. The gained results expressed even worse picture that this attempt from the last budget period even deteriorated the situation.

In 2012 EU published report and stated that GDP is not sufficient as measure of macroeconomic performance. To better reflect progress of societies, it should be complemented by measures on environmental sustainability and social inclusion. They gave recommendations for better measuring system. These are: „Recommendation 11: Sustainability assessment requires a well identified dashboard of indicators and Recommendation 12: The environmental aspects of sustainability deserve a separate follow-up based on a well-chosen set of physical indicators ..." (Measuring Progress, Well-being and sustainable development, 2012). This paper is a contribution to the use of composed indicators which would reflect influence of a nowadays dominant EU policy: granting to the sustainable development of EU.

The results which came out of this research prove that HPI is negatively correlated to the paid grants per capita and this means that funding performed by the EU did not improve sustainable development of CEE countries, HPI is getting even lower (Global Footprint Network, 2016).

In countries which succeeded to realize more projects the implementation of ecology is not sufficient, though EU policy is pushing such goals.

It should be that if paid grants are increasing, the ecological footprint is falling down. This is due to the request that projects should improve ecological issues what the main goal of EU policies is. When analyzing details, elements of HPI, although such trend is expected, this is not a case. The paid EU grants data and HPI indexes should be negatively correlated, but they are not. Just the opposite, they are positively correlated. This leads to the conclusion that EU funds have not led to the more sustainable living in CEE countries.

Only the indicator of wellbeing: better sense of living, as outcome from the interviews with residents, is sinchronized with used EU grants (increasing with better use of grants). 
In answers of CEE citizens stays that they find their lives getting improved. There are some other EU reports which show that on a scale of 0 to 10 nearly $80 \%$ of European residents rated their overall life satisfaction in 2013 at 6 or higher. An average satisfaction is 7.1. Bulgaria was ranged with 4.8, Portugal, Hungary, Greece and Cyprus with 6.2 and Finland, Denmark and Sweden with 8.0. Women and men were nearly equally satisfied. Younger EU citizens were more satisfied than elder groups (Quality of life in Europe facts and views - overall life satisfaction, 2015; Oguz et al., 2013). Such reports do not include influence of EU grants.

Investigation from this paper proves that satisfaction of Central European countries' residents is result of intensive consumption of natural resources which should be sparing and kept for the future generations.

An additional factor which is evident is Inequality between people within one country. It is a measure of unequal conditions to reach the life goals. The difference is getting deminishing with more intensive use of grants.

\section{Conclusions}

The hypothesis 1 that wellbeing is improved by EU funds is proved. The significant positive correlation between wellbeing and consumption of EU grants proves that EU funding support is improving humans' feeling about better lives.

The results of authors' investigation rejected the hypothesis 2 that EU funded projects are leading CEE countries to the sustainable development. If the HPI factor is accepted as an index which reflects sustainable development of a country, than significant negative correlation proves that CEE countries do not improve their sustainable road to the future when using EU grants. It reflects that the most of residents are satisfied but the level of ecological constrain to reach this satisfaction is too high what leads to the big ecological problems of the Earth.

The authors warn that evaluation of formal procedures during implementation of projects, which is elaborated by the EU administration in details, is not sufficient. It should be more careful selection of EU programs goals and rigorous control of outcomes in terms of realized objects, elaborated trainings, finished documentation. This control must be by high educated experts. The indicators of the sustainable projects' life after its ending should be developed. It must be permanent monitoring process. EC bodies should permanently publish reports to make outcomes and best practices visible. HPI index should be one which must be permanently monitored, but not the only one. EU should develop mechanisms for the measurement of qualitative results. Only measurable indicators could show need for corrections of measures which reflect EU development. The right measurable indicators should trace the road to Europe sustainable future.

Creating an European sustainable development scoreboard is a necessity.

The recommendations of authors are the following:

- Tracing of „,zero energy“ households, local communities, regions

- Tracing „eco-industrial parks” with closing material loops which compose production systems in one region in the way that one system is using the outcomes of the previous one and is feeding the following production plant or service unit (Ehrenfeld \& Gertler, 1997). 
- $\quad$ Tracing eco efficient objects

- Tracing reciklying systems

- $\quad$ Tracing water waste systems

- $\quad$ Tracing renewable energy systems

- Tracing eco farms, eco food production

be provided.

Real-time information on the general spending of EU funds for decision-making must

- $\quad$ Accurate reports on projects distribution and on inequalities in applying and implementation results between:

$\begin{array}{ll}> & \text { Countries } \\ > & \text { Programs } \\ > & \text { Sectors } \\ > & \text { Calls within programs } \\ > & \text { Programs measures, goals... } \\ > & \text { Project applicants and partners. } \\ > & \text { Extends national financial accounts to: } \\ > & \text { Environmental (specially energy and waste) part } \\ > & \text { Food chains part } \\ & \text { Water chains part }\end{array}$

The reaction of EU bodies must be quick in order to take control over its budget spending and make members aware of the common goals towards better human and nature wellbeing.

\section{References}

Adelle, C., Pallemaerts, M. \& Baldock, D. (2008). Turning the EU budget into an instrument to support the fight against climate change. ISBN 9789186107000. Swedish institute for European policy studies, pp. 63.

Retrievied Jun 05, 2016, from http://www.ieep.eu/whatsnew/newsitem.php?item=158

Atkinson, A. (1970). On the measurement of inequality, Journal of Economic Theory, Volume 2(3), ISSN: 00220531, pp. 244-263.

Asefa, S., Kalamazoo, M. (2005). The Economics of Sustainable Development, W.E. Upjohn Institute for Employment Research, pp. 1-18. Retrieved July 15, 2015, from http://dx.doi.org/10.17848/ 9781417596324.

Bao, F., Weng, J. (2011). Information security. Practice and experiences, 7th International Conference, ISPEC 2011, Proceedings, China, pp. 351.

Berica, C. (2010). Factors that influence the low rate of structural funds absorption in Romania, Centre for European studies CES Working Papers, II, (4), Iasi, University of Iasi.

Retrieved Mai 16, 2016 from http://cse.uaic.ro/WorkingPapers/index.htm

Borucke, M., Moore, D., Cranston, G., Gracey, K., Iha, K., Larson, J., Lazarus, E., Morales, H., Wackernagel, M. \& Galli, A. (2012). Accounting for demand and supply of the biosphere's regenerative capacity: the National Footprint Accounts' underlying methodology and framework, Ecological Indicators, Volume 24, ISSN 1470-160X, pp. 518-533, 10.1016/j.ecolind.2012.08.005.

Cameron, E \& Joas, M. (2007). EU Support for Cities towards Sustainable Development - An Empirical Study about Failure or Success at the Local Government Level, Åbo Akademi University

Case, C., Case, S., Nicolaescu, V. (2011). Absorption of structural funds in Romania, Romanian journal of economic forecasting, 2/2011, pp. 84-105.

Cohesion fund. (2015). Retrieved July 05, 2016, from http://ec.europa.eu/regional_policy/en/funding/cohesion-fund/ 
Ehrenfeld, J., Gertler, N. (1997). Industrial Ecology in Practice The Evolution of Interdependence at Kalundborg. Journal of industrial ecology. Massachusetts Institute of Technology and Yale University, Volume 1, Number 1, doi: 10.1162/jiec.1997.1.1.67.

EU budget at a glance (2015). European Commission. ISBN: 978-92-79-44368-8, doi: 10.2761/203060, Luxembourg: Publications Office of the European Union

EU funds in Central and Eastern Europe (2014), Progress report 2007-2013, Budapest: KPMGs public sector team.

Europe 2020. (2010). Retrieved January 25, 2016, from http://ec.europa.eu/europe2020/index_en.htmdoi:10.3386/w17967

European social fund. (2014). Retrieved July 15, 2016 http://ec.europa.eu/esf/home.jsp

European Structural and Investment Funds. (2014). Retrieved May 17, 2016, from http://ec.europa.eu/regional_policy/en/funding/

Eurostat-Population. Retrieved January 31, 2016, from http://appsso.eurostat.ec.europa.eu/nui/show.do?dataset=demo_gind\&lang=en

Ewing, B., Moore, D., Goldfinger, S., Oursler, A., Reed, A. \& Wackernagel, M. (2010), Ecological Footprint Atlas 2010, Global Footprint Network, Oakland

Galli, A., Wackernagel, M., Iha, K. \& Lazarus, E. (2014). Ecological Footprint: Implications for biodiversity, Biological Conservation, Volume 173, pp. 121-132, doi:10.1016/j.biocon.2013.10.019.

Georgescu, G. (2007). Determinants of increasing EU funds absorption capacity in Romania, Annales Universitatis Apulensis Series Oeconomica, Bucurest, Vol.1, pp. 63-75, Retrieved Jun 12, 2016, from

http://www.oeconomica.uab.ro/upload/lucrari/1020082/16.pdf

Georgieva, K. (2014). Financial Report 2014. Europa. European Commission.

Gherghinescu, O. (2010). Econometric model for analysing the structural funds absorption at regional level - sectoral operational programme human resources development, Annales Universitatis Apulensis Series Oeconomica, Bucurest, 12(2), 2010, pp. 550-562.

Retrieved 12 February, 2016 from http://oeconomica.uab.ro/upload/lucrari/1220102/05.pdf

Global Footprint Network (2016). Data and Results: National footprint accounts. Retrieved September 08, 2016 from http://www.footprintnetwork.org/en/index.php/GFN/page/footprint_data_and_results

Happy Planet Index 2016. (2016). New economic fondation, Retrieved Mai 13, 2016, from

http://ec.europa.eu/budget/reform/budget_glance/what_for_en.htm

Kalman, J. (2010). Posible structural funds absorption problems, The Political Economy View with Application to the Hungarian, Regional Development Institutions and Financial system, Budapest, OSL/GI, pp. 1-45.

Kettunen, M. \& Gantioler, S. (2014). Brussels in brief, Finnish environment institute, Helsinki, Finland, World conservation union.

Kitzes, J, Peller, A., Goldfinger, S. \& Wackernagel, M. (2007). Current Methods for Calculating Nation al Ecological Footprint Accounts, Science for Environment \& Sustainable Society, Vol.4, No.1, Research Center for Sustainability and Environment Shiga University, pp. 1-9.

Kitzes, J., Wackernagel, M., Loh, J., Peller, A., Goldfinger, S., Cheng, D. \& Tea, K.

(2008). Forthcoming Shrink and Share, Humanity's Present and Future Ecological Footprint, pp. 230-235.

Knezevic, I. (2010). Absorption Capacity of Serbia for Use of EU Funds: Practical Lessons from Slovakia.The project is financed by the SlovakAid, Beograd, European Movement of Serbia Retrieved August 1, 2015 from www.centaronline.org

Marinov, V., Bahloul, H., Slay, B. (2006). Structural funds and the new member states: lessons learned, London, Development \&Transition, issue 4, pp. 15-25, UNDP, London school of economics.

Marks, N., Abdallah, S., Simms, A. and Thompson, S. (2006). The (un)Happy Planet Index. London: New Economics Foundation.

Measuring Progress, Well-being and sustainable development (2012).The response of the European statistical system to the report of the Stiglitz-Sen-Fitoussi Commission and to the 'GDP and beyond' Communication of the European Commission, ISBN 978-92-79-22147-7 doi: $10.2785 / 21299$

Methodology and Sources (2016). Retrieved July 08, 2016, from http://www.footprintnetwork.org/en/index.php/GFN/page/methodology. 
Naderi, K., Bahrami, A., Aazami, M. \& Sheklabadi, M. (2015). Asessment of Agricultural Farming Systems Sustainability in Hamedan Province Using Ecological Footprint Analysis (Case Study: Irrigated Wheat), Journal of agricultural science and technology, ISSN: 1680-7073, Article 3, Volume 17, Issue 6, pp. 1409-1420.

Oguz, S., Merad, S. \& Snape, D. (2013). Measuring National Well-being - What matters most to Personal Well-being? Office for National Statistics, London.

Perkins, D., Hughey, J. \& Speer, P. (2002). Community psychology perspectives on social capital theory and community development practice, Journal of the Community Development Society, Vol. 33, No. 1, Taylor \& Francis Group, doi:10.1080/15575330209490141.

Q\&A on Interinstitutional Agreement on Budgetary Discipline and Sound Financial Management 20072013. (2006). Retrieved February 17, 2016, from http://europa.eu/rapid/press-release_MEMO06-204_en.htm.

Regional policy. (2015). Regional policy in your country

Retrieved Jun 05, 2016, from http://ec.europa.eu/regional_policy/en/funding/erdf/

Sachs, J. (2014). From Millennium development goals to sustainable development goals, Earth Institute, Columbia University, New York, USA, Lancet, 379: 2206-11.

Retrieved December 03, 2015, from http://peoplebuildingbettercities.org/wpcontent/uploads/2013/04/MDGs-to-SDGs-Lancet.pdf

Senik, C. (2014). Wealth and happiness, Oxford review of economic policy, Volume 30, Issue 1, pp. 92-108, Oxford university press, doi: 10.1093/oxrep/gru004.

Soubbotina, T. (2004). Beyond economic growth an introduction to sustainable development, Second Edition, The World Bank Washington, D.C.

Statistics how to. (2016). WordPress Retrieved July 28, 2015, from http://www.statisticshowto.com/how-tocompute-pearsons-correlation-coefficients/

Stoll, L., Michaelson, J. \& Seaford, C. (2012). Well - being evidence for policy: A review. London: New Economics Foundation.

Streimikiene, , D., Klevas, V. \& Bubeliene, J. (2007). Use of EU structural funds for sustainable energy development in new EU member states, Renewable and Sustainable Energy Reviews, Volume 11, Issue 6, pp. 1167-1187, doi:10.1016/j.rser.2005.07.006.

The EU budget for 2007-2013 (2014). Retrieved July 08, 2015, from http://ec.europa.eu/budget/prior_future/fin_framework_en.htm

Tartar, M. (2010). Estonian Local Government Absorption Capacity of European Union Structural Funds, Tallinn, Halduskultuur - Administrative Culture 11 (2), pp. 202-226.

Thompson, S., Abdallah, S., Marks, N., Simms, A. \& Johnson, V. (2007). The European unHappy Planet Index. An index of carbon efficiency and well-being in the EU, New economics foundation, London, United Kingdom.

Total greenhouse gas emissions by countries (including international aviation and indirect $\mathrm{CO} 2$, excluding LULUCF), million tonnes of CO2, equivalents, Retrieved July 15, 2015, from http://ec.europa.eu/eurostat/statistics-

explained/index.php/File:Total_greenhouse_gas_emissions_by_countries_(including_internationa 1_aviation_and_indirect_CO2,_excluding_LULUCF),_1990_-

_2014_(million_tonnes_of_CO2_equivalents)_updated.png

Quality of life in Europe - facts and views - overall life satisfaction. (2015).

Retrieved August 6, 2016 from http://ec.europa.eu/eurostat/statisticsexplained/index.php/Quality_of_life_in_Europe_-_facts_and_views_-_overall_life_satisfaction

Veenhoven, R. (1996). Happy Life Expectancy: A comprehensive masure of quality of life in nations. Social Indicators Research, vol. 39, pp.1-58.

Zaman, G., Georgescu, G., (2009). Structural fund absorption: A new challange for Romania?, Romanian journal of economic forcasting, 1/209, pp. 136-154.

Zidanšek, A. (2007) Sustainable development and happiness in nations, Third Dubrovnik Conference on sustainable development of energy, water and environment systems, Volume 32, Issue 6, pp. 891-897.

2007 to 2013 ERDF programmes and resources. (2013). Business and enterprise - guidance, Department for Communities and Local Government, Retrieved July 05, 2016, from https://www.gov.uk/guidance/erdf-programmes-and-resources. 